\title{
Oil and Gas Industry Contents Development Act 2010 (Local Content) Law and Challnges in Nigeria
}

\author{
Samuel Chisa Dike PhD \\ Associate Professor of Energy Law and Head of Department Jurisprudence and International Law; Rivers State \\ University, Portharcourt,Nigeria \\ I want to express my gratitude to my LLM candidates Mr. JOHN CHIOMA NAOMI for his research in the area \\ of local contents
}

\begin{abstract}
Any policy, law or regulatory framework that adds value to the indigenous host country's goods, services and human beings has in it the local or indigenous content. An examination of the Oil and Gas Contents Development Act 2010 in Nigeria will show significant progress made in the foray of the hitherto the dark horse - indigenous oil and gas companies into the elite oil and gas class previously 'reserved' for the Multinational Oil and Gas Corporations. This was made possible by the emerging local content laws. However, a lifting of the veils of its actual performance, would reveal both latent and patent challenges facing the application of local contents laws particularly in Nigeria., This paper examines the operations of the Nigeran Oil and Gas Contents Development Act 2010, the challenges and possible recommendations on how to bring it in line with the best global practices. This paper found amongst others that infrastructural and capacity development are the power- base to driving effective local content application anywhere but are sadly lacking in Nigeria. It also found that the Nigerian version of the local contents law tilts towards protectionist regime rather than liberal approach and that a synergy of both frameworks is desired for the smooth operations of local content laws in Nigeria. This paper finally concludes that Nigeria can take a cue from other countries such as Norway and Brazil while considering the peculiarities of the Nigerian oil and gas industry.
\end{abstract}

Keywords Oil and Gas: Local contents law and Practices, challenges and recommendations

DOI: $10.7176 / \mathrm{JRDM} / 65-05$

Publication date:May $31^{\text {st }} 2020$

\subsection{INTRODUCTION}

The Nigerian Oil and Gas Industry Contents Development Act (herein OGCDA) is the cumulative result of decades of attempts by the government and stakeholders in the petroleum industry to ensure that the industry provides local value and maximized benefits to Nigerians and Nigerian companies in the country's oil and gas industry in key areas of human, material, and economic resources ( Subai2019). Initially, the Nigerian oil industry was solely dominated by the international oil companies until Nigerian companies became interested as a result of the introduction of the Nigerian content directives by the Nigerian National Petroleum Company (NNPC) (Omorogbe 1977) Nevertheless, the goal of the Nigerian involvement in oil and gas industry led to the resort to the local content requirements (LCR). The vision of the Government is to transform the Oil and Gas Industry into an economic engine for job creation and economic growth by developing in-country capacity and indigenous capabilitiess ( Amadi, 2020). In the Local Content Act, the Federal Government focused on five areas for development (a) Fabrication and Construction (b) Manufacturing (c) Engineering Design (d) banking and insurance (f) Shipping and logistics (OGCDA Section 57). Nigerian Oil and Gas Industry Content Development Act (NOGIC Act) The main thrust of the NOGIC Act (The Act) is to increase the level of Nigerian Content in the ccountry's oil and gas industry. In the Act Nigerian Content has been defined in the NOGIC Act, as:

"the quantum of composite value added to or created in the Nigerian economy by a systematic development of capacity and capabilities through the deliberate utilization of Nigerian human, material resources and services in the Nigerian oil and gas industry"

In pursuance thereof, the NOGIC Act provides that first consideration shall be given to Nigerian independent operators, goods and services and also to Nigerians in employment and training. All fabrication and welding activities carried out in the industry must be performed in-country. The Act imposes a levy of $1 \%$ on the value of all contracts awarded in the upstream sector. The amount is required to be deducted at source and paid into the Nigerian Content Development Fund (NCDF). The Minister of Petroleum Resources shall consult with the relevant government agencies on the appropriate fiscal incentives to grant to companies who establish facilities, factories, production units or other operations in Nigeria for the purpose of manufacturing goods and providing services which were previously imported. The Act provides for the establishment of the Nigerian Content Development and Monitoring Board (the Board) to monitor, coordinate and implement the provision of the Act. While most countries chose not to enact any legislation wholly on local contents issues, some others prefer to have policy and law protecting their indigenous firms. For the earlier scenario, such countries promote local contents agenda through their licenses and contracts provisos without any specific law on local contents. Nigeria chose to 
promulgate a law with the aim of protecting local industries and developing human and material capacities in the oil and gas trade. This is some attendant advantages and disadvantages which we shall see later in this paper. However, some key issues aggravated the need for the protection of local manpower and local infrastructure.

\section{Drivers of the Local Contents Law in Nigeria.}

The oil and gas industry were the exclusive preserve of the seven sisters who dominated the oil and gas trade for many decades before the establishment of national oil companies (Omorogbe, 1997). The indigenous host oil producing countries were alienated due to lack of expertise and technological knowhow. The seven sisters, who later became the forbearers of other International oil companies and contractors in the oil and gas industry were vertically integrated as they had their activities covering upstream, midstream and downstream to the exclusion of the host oil producing nations (Christopher, 2009). This domination actually frustrated the owners of the oil and pushed their agitations and frustration to recover their rights (Oke, 2012). This led to chains of development which culminated in the confidence of the host oil and gas countries to compete with their International oil and gas companies. As at today, the national oil companies have greater control of proven oil reserve globally than the IOCs and these indigenous oil companies are equally engaged, like the IOCs, on all sectors pf the industry, including upstream, midstream and downstream sectors (Dike2015). Indeed, this a paper argues that the main drivers to the establishment of the Local content Act are:

a. The domination of the early industry by seven sisters in the oil and gas industry for long-time.

b. Failure to pay tax and remit royalties commensurate to the crude oil obtained during the concession era.

c. The disappointment of the host oil and gas producing countries (OGPC) over the general attitude of the IOCs in the control and management of their natural resources

d. The formation of OPEC by IRAN, IRAG, VENEZUELA, KUWAIT, SAUDI.LYBIA (OPEC 1960)

e. The rise of national oil companies in the host (OGPC) through the acquisition of the oil and gas knowledge and technology.

f. The various United Nations Declarations on Permanent Sovereignty and proper management of natural resources of the OGPC.

g. Failure to transfer technology to OGPC and to develop indigenous capacity by IOCs

$\mathrm{h}$. The poor management of the natural resources by the OGPC and the associated problem of resource curse.

i. The need to meet sustainable development targets in the host OGPC which the oil industry has failed to provide coupled with the fact that oil and gas crowds out other economic and agricultural sectors.

j. The failure of the existing laws to capture adequate local participation and control over the activities of the IOC and the oil industry in general (Nawokolo,2012).

The local content clauses in the Petroleum Act 1969, which coordinates and control oil and gas activities in Nigeria did not frontally address local capacity development, hence the promulgation of the OGCD Act 2010 (Petroleum Act 1969). The paper makes some conceptual clarifications by defining terms such as 'local content' and the 'Nigerian company'. The legal and institutional framework is also clearly set out. The institutional -framework considered in this paper includes the role of the Nigerian Content Development and Monitoring Board (NCDMB) and its main functions and challenges. The paper goes further to consider local content in other jurisdictions such as Angola, Equatorial Guinea and Norway. Some of the challenges of the local Content Act in Nigeria were discussed while recommendations were made to bring the Nigerian brand of local contents law in line with modern trends.

\subsection{Conceptual Framework of Local content:}

The World Bank defines Local Content As "A Policy that Has Evolved from Creating Backward Linkages by Supplying Input to the Local Economy through Transfer of Technology, the Creation of Local Employment Opportunities, And Increasing Local Ownership and Control". Furthermore, it is considered as the added value brought to a host nation (national, regional and local areas in that country, including communities) through the activities of the oil and gas industry. This may be measured (by project, affiliate, and/or country aggregate) and undertaken through activities which mainly include work force development (international oil companies/national oil companies, contractors/sub-contractors), supplier development (all oil and gas goods and services), and community development. The OGCDA defines local content as "the quantum of composite value added to or created in the Nigerian economy by a systematic development of capacity and capabilities through the deliberate utilization of Nigerian human, material resources and services in the Nigerian oil and gas industry." (OGICDA2010). For the national oil company (NNPC) Nigerian Content" vision is to transform the oil and gas industry into the economic engine for job creation and national growth by developing in-country capacity and 
indigenous capabilities. In this way, greater proportion of the work will be done in Nigeria with active participation of all sectors of the economy and ultimately Nigeria will be positioned as the hub for service delivery within the West African sub region and beyond.

\subsection{The Nigerian Company:}

Section 106 of the Act defines Nigerian Company as A company founded and registered in Nigeria under the provisions of the Companies and Allied Matters Act with at least 51\% of equity shares owned by Nigerian".

The Act provides special privileges to all Nigerian companies that operate in the Oil and gas industry. It insists on the development of the production of Nigerian material to be a key relevance in the oil industry projects and operations. The Act emphasizes that for the award of contracts, oil blocks and so on, first consideration should be given to Nigerian operators. This rule also applies to other aspects like purchase of goods and services, employment of staff/training etc. Exclusive consideration is given to Nigerian local service firms demonstrating ownership of machinery, Nigerian workers and capability to carry out such operation on land and wetlands.

\subsection{Main Provision of the Local Contents Act 2010}

The Nigerian Oil and Gas Industry Contents Development Act, has 107 sections and one schedule and by the provisions of section 1, the Act supersedes all previous legal provisions relating to local content in the oil and gas industry. This implies that the insufficient or deficient provision in the Petroleum Act 969 and other related legislation are subsumed under the present Act. Accordingly, it may be argued that the OGCDA overreaches all other legislation on the petroleum industry. Section 2 mandates that the Nigerian Content should be considered as an important element in the overall project development and management philosophy for project execution. The Act provides for the establishment of the Nigerian Content Development and Monitoring Board (NCDMB) to monitor, coordinate and implement the provisions of the Act. It is conferred with the exclusive responsibility for the regulation and development of the Nigerian content in the upstream and downstream sub sectors including the responsibility of operating an e-marketplace, a Joint Qualification System (JQS) and the provision of support for indigenous firms in their bid to develop their competencies within the Oil and Gas Industry. The Board is involved in every stage of the Petroleum Industry from pre-contract to execution and post - execution. The Act also established the Nigerian Content Consultative Forum to provide the platform for information sharing. Operators are required as a precondition to the award of any contract to submit a Nigerian Content plan to the NCDMB from the stage of bidding for a license, permit or other oil and gas interest. (OGCDA s. 7) Such a plan showing compliance with the Nigerian content requirements of the Act is also required to be submitted before the execution of any project in the industry. The target of the Act was to create 300,000 direct jobs and retain in Nigeria, capital flight of billions of dollars while setting a target of achieving $70 \%$ local content by the year 2020 which has failed. However, the Nigerian Content Development Monitoring Board in 2017 adopted a ten-year strategic road map focused on ramping Nigerian content to 70\% by the year 2027 (Amadi and Abraham, 2019). The Act is expected to significantly change the current business and operating structure in the Nigerian oil and gas industry where hitherto over $80 \%$ of work value in the industry were executed outside the shores of Nigeria. The examination of the function of the board would be of great asset to this paper.

\subsection{Nigerian Content Development and Monitoring Board (NCDMB)}

The Nigerian Content Development and Monitoring Board was established by section 69 of the Local Content Act as a body corporate with Head office located in any of the oil producing states in Nigeria. The Board consists of a Governing Council which is empowered to conduct the affairs of the Board (OGCDA s7(1) (1) The Council equally consists of four directorates namely; the Directorate of Finance and Personnel Management, the Directorate of Planning, Research and Statistics, the Directorate of Monitoring and Evaluation, the Directorate of Legal Services and any other Directorate which the Council may establish. The Board shall also consist of a Chairman who shall be the Minister of Petroleum Resources, an Executive Secretary, who shall be the Secretary of the Council amongst others. The structure of the Board is fully set out in section 72 of the Local Content Act with the functions covering the following:

a. To review, assess and approve Nigerian Contents plans developed by operators

b. To set guidelines and minimum content levels for project related activities across the oil and gas value chain.

c. To engage in targeted capacity building interventions that would deepen indigenous capabilities- Human Capital Development, Infrastructure \& Facilities, Manufactured Materials \& Local Supplier Development.

d. To grow and manage the Nigerian Content Development Fund

e. To establish, maintain and operate the Joint Qualification System (NOGICJQS) in conjunction with industry stakeholders.

f. To monitor Nigerian Content Compliance by operators and service providers. This will be in terms of cumulative spending, employment creation and sources of local goods, services and materials utilized on 
projects and operations.

g. To award Certificate of Authorization for projects that complies with Nigerian Content provisions.

$\mathrm{h}$. To conduct studies, research, investigation, workshops and trainings aimed at advancing the development of Nigerian Content. The NCDMB in conjunction with NMASA shall have powers to enforce compliance with relevant sections of the Coastal and Inland Shipping (Cabotage) Act 2003 in relation to matters pertaining to Nigerian content development.

\subsection{Structure and Regulatory Approach that depict Protectionist Regime in the Act First Consideration}

The content plan to be furnished must contain provision to ensure that first consideration" is given to (a) Nigerian Independent operators, goods and services and (b) Nigerians in employment and training. Section 3(1) of the NCA provides that "Nigerian independent operators shall be given first consideration in the award of oil blocks, oil field licenses, oil lifting licenses... subject to the fulfillment of such conditions as may be specified by the Minister." Similarly, the term "first consideration" is not defined, however, the Board expects the operator to indicate how 'first consideration' is considered assessed and applied by it in the evaluation of bids. In any case, the plan must contain details as to the criteria to be used by the operator and its contractors in assessing how first consideration is to be given to Nigerians in the process of evaluating bids for goods and services required by the project including details as to how the use of locally manufactured goods which meet the industry standard is to be ensured.

It is not clear how the Board will determine whether the criteria used by the operator in determining first consideration are acceptable. Are these subjective criteria to be determined by the Board on a case by case basis or is the Board to take advantage of the provision authorizing it to conduct a public review in relation to the exercise of any of its functions under the Act to determine the proper criteria for "first consideration" where question arise. However, the Board, has 30 day from the date of commencement of assessment to issue or deny the certificate of authorization for that project. We argue that first consideration without qualification of availability of competence and expertise promotes a protectionist regime in an industry which is liberal in outlook.

\subsection{Exclusive Consideration}

Exclusive consideration is required only once in the Act. This is pursuant to section 3(2) which provides that Nigerian indigenous service companies which demonstrate ownership of equipment, personnel and capacity to execute shall be given "exclusive consideration" to bid on land and swamp operating areas of the Nigerian oil and gas industry for contracts and services contained in the schedule to the Act. Section 15 of the Act requires that all operators should maintain a bidding process for acquiring goods and services, which shall give full and fair opportunity to Nigerian indigenous contractors and companies. Again "full and fair opportunity" is not defined, however in practice, it would require that Nigerian companies are given adequate notice of tenders and have access to the necessary information required to bid as their foreign counterparts would. This in itself does not appear to be a discriminatory measure and only seeks to ensure that Nigerian companies are treated in an equitable manner. The Act also provides that the award of contract shall not be based solely on the principles of lowest bidders and provided that the Nigerian company's bid does not exceed the lowest bid price by $10 \%$, where the bids are within $1 \%$ of each other at the commercial stage; the bid containing the highest level of Nigerian content shall be selected provided the Nigerian content on the selected bid is at least 5\% higher than its closest competitor. This is bit protectionist as the bid of a Nigerian must be considered even if others meet the required value. Compliance with Minimum Nigerian Content Specifications; Operators are mandated to comply with minimum specifications for Nigerian content as contained in the schedule to the Act. The schedule specifies certain criteria to be followed which includes the number of Nigerian man hours utilized in relation to the duration of the project, tonnage, size and volume of certain goods, level of certification obtained and the total amount of local expenditure in relation to the procurement of local goods and services. In other words, operators are mandated to invest in, setup facilities or factories or operational units within Nigeria for the purpose of carrying out any production, manufacturing or provision of services which otherwise would have been imported from overseas. Operators are permitted to deviate from these specifications where local capacity is inadequate upon authorization by the Minister. Such authorization shall not be given for a period exceeding three years within which time local capacity is expected to have been built in the relevant area. Additionally, under section 34 of the Act, where a project or contract value exceeds $\$ 100$ million (USD), it shall contain a labor clause mandating the usage of a minimum percentage of Nigerian labour in specific cadres as may be stipulated by the Board. Section $41(2)$ also requires that a minimum of $50 \%$ of the equipment deployed for execution of work carried out by local subsidiaries of international/multinational companies are owned by the subsidiaries.

\subsection{Submission of Certain Documentation for Bid Tenders and Contract Awards for Projects in Excess of $\$ 1,000,000$ (USD)}

Section 17 to 24 cover this area. Thus, any project in excess of \$ 1 million Dollars can only commence subject to 
the authorization of the Board who will issue a Nigerian Content Compliance Certificate (NCCC). Sections 17 to 24 of the Act make provisions for documents which must be submitted by operators for the approval of the Board in this regard in the areas of advertisements, prequalification criteria, technical bid documents, technical evaluation criteria and the proposed bidders' lists as well as other relevant information. 30 days prior to the first day of each quarter, Operators are also to notify the board of all contracts, subcontracts and purchase orders in excess of $\$ 1$ million which will be bided for or executed in the upcoming quarter. Prior to the issuance of adverts or prequalification notification to prospective bidders, operators shall submit details of the scope of work, the relevant notification where necessary, list and head office locations of targeted companies and time frame for the prequalification stage. This procedure is also required prior to the issuance of an invitation to tender and prior to the award of contract, subcontract or purchase order to the selected bidder with specific information required for each stage. By virtue of sections 25 to 27 of the Act, prior to the carrying out of project in Nigeria, an operator might be required to establish a project office in the catchment area where the project is to be located, managed by approved personnel who shall exercise decision making powers with regard to the project execution and the Board might also require an operator to maintain offices in a community where the operator has significant operations.

\subsection{Employment and Training of Nigerian Personnel and Expatriate Quota Regulation.}

An operator must give Nigerians first consideration for employment and training in respect of all executed projects and may be required by the Board to maintain a reasonable proportion of employees from areas of significant operations. Submission of an Employment and Training Plan which shall include hiring and training needs of the operator, and its contractors, breakdown of required skills and shortages in the Nigerian labour force and anticipated training requirements and expenditure for such training. A time frame for employment opportunities for each project phase. Specific quarterly reports of the employment and training activities of the operator. Evidence of reasonable efforts by operator to within a reasonable time, train Nigerians to fill skills shortages in the industry. Submission of succession plan for the Materialization of expatriate positions. Appeal of the Board must be sought prior to the application to the relevant authority for expatriate quota positions. A maximum of 5\% of expatriates may be maintained by an operator for management positions in respect of each project. The Act also empowers the Minister to make regulations requiring compulsory registration of operators, companies, or its professional employees engaged in the provision of engineering or other professional services in the petroleum industry with relevant professional bodies in Nigeria. This presents another avenue for monitoring importation of expertise and ensuring that this only happens where such expertise is not available locally. Operators are mandated to employ only Nigerians in their junior and intermediate cadre. This create rooms for the employment of professional and consultants in Nigeria.

\subsection{Obligations for Research and Development}

The operator is required to carry out a Research and Development $(R \& D)$ program in relation to its work program and activities for every project. This shall include a bi- annual update of the operator's R and D Plans and a quarterly report of operator's $\mathrm{R}$ and $\mathrm{D}$ activities. These plans will outline revolving three-five-year strategies which the operators intend to fulfill. It will also include a breakdown of expected expenditure for implementation of the targets set as well as strategies through which members of the public may submit proposals for R\&D. The R and $\mathrm{D}$ obligations of the operator shall be in conformity with the provisions of regulations to be made by the Minister with respect to targets to be met for the growth of R and D in the industry. In other to ensure a faster and smoother compliance of this all-important requirement of the Act, the Federal Government must create the enabling environment by providing basic infrastructure such as steady power supply, clean water and security which are vital for research development.

\subsection{Technology Transfer Obligations}

The Act provides that the Operators develop an acceptable program to promote technology transfer and submit an annual plan for promoting the effective transfer of technologies from the operator and alliance partners to Nigerian individuals and companies. Other provisions of the Act in this regard stipulate collaboration between Nigerian and foreign contractors and service or supplier companies with the submission of an annual report of such initiatives. One hopes that this coloration will not mortgage the essence of local impute of certain projects It could also be agues that while most countries will not easily transfer technology unless there is some enabling environment and or reciprocal treaty or understanding with the receiving country, Nigeria should prepare for a technologically driven institutions and centers for this to happen.

\subsection{Insurance, Financial and Legal Services Provisions}

Sections 49 to 53 of the Act mandate operators to utilize local insurance, financial and legal services in their project implementation. Operators must also submit a bi-annual report to the Board detailing the nature of the services so utilized, the budget as well as actual and projected expenditure. 


\subsection{Annual Nigerian Content Performance Report.}

The Annual content Plan is to be submitted by the operator to the Board for evaluation within sixty days of the beginning of each year covering all its projects for the relevant year and specifying its category of expenditure and its employment and procurement achievements (OGCDA, s104). To facilitate proper monitoring and verification of the reported activities, operators and their contractors are required to allow access to their facilities and provide relevant documentation to the Board and its designated agents.

\subsection{Payment for Nigerian Content Development Fund (NCDF)}

Under the Local Content Act, Operators, Contractors, Sub-contractors and their Alliances are required to pay 1\% of their total contract sum awarded in the upstream sector into the Nigerian Content Development Fund (NCDF) for the purpose of implementing the Act .However, the major questions which this provision raises for the stakeholders in the industry are as follows: To whom does this provision apply and to what extent does this requirement apply? These questions arise in situations where a company is awarded a contract and subsequently sub contracts it after paying the mandatory $1 \%$ levy, would the subcontractor have to pay the levy again and if the same scope of contract is further sub contracted over and over, would all those to whom it was subcontracted to all pay the $1 \%$ levy?. The answer to these questions is yes according to the Board. This is to create a situation where it is economically unviable to subcontract after obtaining a contract on the basis of meeting minimum Nigerian content requirement. The stakeholders in the industry have also argued that all these additional costs brought on by the multiple applications of the levy is ultimately transferred to major Exploration and Production companies and that the Nigerian Government gets to pay at least $55 \%$ of the cost at the end of the day so that it may be counterproductive at the end of the day (Business World 2019) The Operating and Oil and Gas Companies that default in remitting the $1 \%$ levy to the Nigerian Content Development Fund would be blocked from participating in the Industry tendering processes. Further, the erring Company would also be suspended from getting statutory clearances such as processing the expatriate quota applications (OGCDA 2014)

\subsection{Tax Incentives}

Tax incentive is granted to operators and, their contractors, subcontractors which establish facilities, factories, production units or other operations within Nigeria for the purpose of manufacturing goods or providing services which were previously imported. The whole idea behind this tax incentive is to encourage the inflow of investment and to expand the country's production base as well as encourage the stakeholders to comply with the provisions of the Act.

\subsection{Penalties}

Failure by operators and their contractors and sub-contractors to comply with the provisions of the Act in their operations is an offence punishable by a fine of $5 \%$ of the project sum for each of the projects in which the violation occurs or the total cancellation of' the project. It is noteworthy also that the operators' eligibility for the award of licenses, permits and other interests in petroleum operations would be based on the operator's compliance with provisions of the Act. In addition to the said deduction, the Board will prosecute such an offender in accordance with the provision of the Act.

\section{Local Content Policies in Other jurisdictions. 6.1 Brazil}

It is well known that many resources - rich developing countries, particularly in African, have not benefited satisfactorily from the exploitation of their natural resources. For this very reason the countries are placing increasing emphasis on the need to derive more benefits from their natural resources. Local content policies have been adopted by some countries as a development strategy aimed at increasing the benefits from the oil and gas sector. Even the established oil and gas countries have leveraged local content policies to developed their petroleum industry. Although some of these countries adopts a mixed protectionist and liberal approach depending on peculiar circumstances which the infusion of local content policies was a gradual effort in This paper will examine Brazil and Norway being a federal state and a unitary state. These are oil and gas producing and exporting countries with established pedigree on oil and gas development. Brazil is an oil and gas producing and exporting country with established oil and gas province both onshore and offshore. Brazil's main national oil company is Petrobras while the regulator is ANP. Brazil adopts both concession joint venture on its acreage management. However, the initial concessionaries were governed by local content policies that protected the local firms (Bunter 2002), While, the concessions system governs Brazilian onshore acreages, the PSC was the regime that covers Brazilin pre salt areas. The ANP was a party to all concessionary agreement with IOCs on behalf of the State. This agreement includes the need for environmental protection, use of local firms, capacity and infrastructural development. Most of the IOCs under the concession sourced local workforces and materials from Brazil based on a greed percentage with ANP which it made a condition precedent for the award of any license in exploration. 
Fines were imposed on defaulting firms that failed to utilize local contents in exploration and production. Most of the fines were commensurate to the level of impunity or disregards of the local content policies in Brazil. To demonstrate the seriousness attached to local content, the fines were both imposed on Petrobras as with other IOCs in a non-discriminatory manner. The Brazilian local content policies ware considered protectionist in that it led to the exodus of Explorations and Production firms out of brazil (ANP 2020). This made the Storting- the Brazilian Parliament and ANP to rethink the policies on local content; utilization and implementation in Brazil. Local content and cash bonus were the main consideration for Brazilian four licensing rounds. This development face had different percentage requirements of local imputes while exploration stage has its special requirements. The protectionist policy in Brazilian Petroleum industry met a brick wall as some IOCs decided to pull out due to the stringent measures attached to the Brazilian Petroleum Industry. ANP and Storing subsequently amended the framework by liberalizing its petroleum sector in 1997 for the exploration phase and $27 \%$ for the development phase reducing the average local content target to $25 \%$ for the exploration phase. The development of pre-salt, which posed so much technical and infrastructural burden that foreign IOC's support and investment became challenging. Thus, its $14^{\text {th }}$ licensing rounds was open to the participation of mixed local and foreign investors. Brazil was thus forced to tone down its protectionist local content regime to a more liberal framework (CMS Law Barazil2002) This relaxation cuts across all streams of the industry from exploration production and differ from onshore to Brazilian pre-salt basin which was considered capital intensive and most difficult to develop. ANP also complements foreign impute by developing local research institutes and grans of scholarship for petroleum technology development.

\subsection{Norway}

Norwegian Petroleum industry is considered one of the best managed industry globally (Hunter, 2014). Norwegian petroleum industry has recorded a number of success in several critical areas in the petroleum industry such as environmental pollution, effective and transparent management of its petroleum revenue, development of a globally competitive and effective state regulation. The Norwegian government has introduced legislation necessitating that companies using natural resources also contribute to economic development; by building bridges and well-defined partnership with Stat oil. The export of offshore oil and gas in Norway began in the mid I96Os and from the 1970s onwards the minister in charge of petroleum started implementing policy to protect the interests of communities and the economy. Its local content strategy has therefore been held up as an example of good practice for other countries. The government aimed to award contracts to Norwegian bidders when they proved to be competitive in terms of price, quality, delivery time and service. The rationale behind this was to promote the establishment of local industry and this was achieved through cooperation with International Oil Companies. When foreign operators started entering the Norwegian industry in the late 1970's they were strongly encouraged to form research and development (R\&D) partnerships and Joint Development Programmes with Norwegian Companies and Institutions, thus engaging in local content growth oversea firm's commitment to and strategies for technology transfer were made a crucial and determining factor in the licensing process by the Ministry of Petroleum and Energy. Government policy meant that Norwegian Oil and gas supply companies developed leading class stateof-the-art technologies and as a result many international companies have located part of their R\&D chain in the country. The competencies and technological expertise developed as a consequence of Norway's local content policy also strengthened its position within international oil industry. Local supply and services provide to oil activities have proved truly competitive by global standard. The country has also passed on its expertise in the area through the Norwegian Oil Development initiatives, aimed at helping developing countries to export oil and gas as a vital resource for economic and social progress. It cooperates with Nigeria, Angola, Iraq, South African etc. working on challenges in local content and industrial development.

\subsection{Evaluation of the OGCDA Act 2010}

This section evaluates the proprietary of the Act and the merits and merits of the Act. The Act adopts a protectionist approach which is consistent with the practice in developing oil and gas host nations. However, there are merits and demerits of this approach. The demerits include:

a. The likelihood of this framework offending international law on competition.

b. May drive away foreign investors and foreign finances.

c. May be counterproductive as the indigenous institutions may be complacent.

d. With the ultimate dependence on foreign technology and finance, a strict Local content law may stifle economic growth and development in poor oil and gas producing countries

The merits include:

a. May promote economic development through the addition of value to local economy

b. May cause the growth of indigenous oil and gas firms

c. May create a healthy competitive spirit between foreign IOCs and local companies

d. May promote sustainable deployment due to multiplier effect. 
The question that may be asked is Whether Nigeria under the Nigerian oil and gas industry content development Act lived up to expectation? The question then is, has the Act lived up to expectations? It is our response that the Act has achieved some fair level of success with a lot more to do. The achievements are as follows (Subai 2010):

Two years after the Act came into existence, the Chief Executive Officer of the Board then, Mr. Ernest Nwapa announced that \$4bil] ion dollars out of \$20 billion estimated for expenditure for the year 2012 was retained in Nigeria due to the impact of the Act. Since then, a lot more foreign exchange has been saved. In the first two years of the Act, $90 \%$ of the engineering required and $50 \%$ of the tonnage for the fabrication of all field development facilities were carried out in Nigeria. It was also reported that within the same time frame, $\$ 2.8$ billion was invested into the oil sector. Significant growth in the participation of indigenous companies in the oil industry and growth in the Nigerian services sector and the companies have been impelled to innovate and develop capacity. Total value of contracts awarded to Nigerian Company have since risen by $83 \%$ while the average Nigerian content retention in-country is about $28 \%$. This has compelled the international Oil companies to factor in local content in their policies and operations and create local content departments in their establishments to ensure compliance with the Act. Encouraging Nigerian companies to take on new challenges in exploration, engineering and fabrication in the Oil and Gas industry which was the exclusive preserve of major Oil operators. An example of this was recorded in 2013 when two indigenous firms Niger Dock and Dorman Long Engineering Ltd fabricated two major well heads for Mobil Producing Nigeria. At the time it was the largest fabrication job executed in Nigeria. Other major fabrication/engineering feats and the most recent in 2018 was the fabrication of six modules fabricated in Nigeria for the Total E\&P's Egina Floating Production Storage and Offloading Vessel at the SHIMCI yard, LADOL Free Zone in Lagos State. Indigenous firms now own, operate and develop marginal oil fields which now account for $15 \%$ of crude oil production. Nigerian service firms have since the Act invested heavily in acquiring sophisticated vessels and rigs erstwhile owned exclusively by major Oil Operators. The Act represents a legislative guarantee to qualified Nigerian firms in the Oil and Gas Industry that they would be preferred for important jobs so long as they have the technical know-how. Also, the Government can borrow a leaf from Norway and Brazil to facilitate R\&D. In Norway, for instance, the government offers preferential access to new concession blocks to oil companies that invest heavily in R \& D with Norwegian researchers in Norwegian Institutions. Brazil makes investment in $\mathrm{R} \& \mathrm{D}$ a condition precedent for executing $\mathrm{E}$ and $\mathrm{P}$ in the pre salt basin with International Oil companies. This will deepen the knowledge base of the Nigerian Oil and Gas industry, ultimately increase local content and attain or maintain a competitive edge. This is a departure from the administrative and nonimplementation of casual provision in the Petroleum Act 1969. The Act is a clear departure from the pa we have in essence under the Act is a more stringent regime which subjects the activities of operators to considerable scrutiny by the Board. The success or otherwise of' the provisions of the Act would thus be substantially influenced by the judiciary and political will exercised by the Board and the Nigerian Government especially in carrying out its task.

\section{7..1 Challenges of the Nigerian Oil and Gas Industry Content Development Act 2010.}

The implementation of the Act is the sole responsibility of the Nigerian Content Development Monitoring Board. Despite the many gains associated with the Act through the efforts of the Board, there have been challenges to mostly in the areas of enforcement, lack of holistic criteria for appropriately measuring Nigeria's local contents requirements and achievements, corruption, weak capacity among others.

Enforcement: The Board in the exercise of its duties to enforce the Act has adopted a largely collaborative and conciliatory approach and is rather slow to issue sanctions. In its dealings with erring companies, it would rather issue notices of non-compliance rather than rely on strict enforcement of the Law including settling and mediating local contents disputes. This lapse on the side of the Board was exploited by some companies; bearing in mind that the worse sanction that will be leveled against them will be the issuance of a notice of non-compliance. We expect that the Board would modify its approach to monitor and ensure compliance using the judicial process. On the hole we found the following as some challenges facing the implementation of the Act:

\section{Lack of strategic Criteria for Measuring Local Content:}

The Board lacks holistic criteria for appropriately measuring the local content and identifying the gaps that should be filled by IOCs It has no measured reward system for compliant by companies and sanctions for the offending companies. In Brazil for instance, the regulator, the National Agency for Petroleum, Natural Gas and B jo-fuel developed a booklet in 2005 known as Cartilha' which is the official methodology for measuring local content in its petroleum industry The booklet defines methods for local content measurements and sets out the criteria for identifying actual manufacturers of components which make up each piece of equipment used in the Brazilian Oil Industry. It also sets out the criteria for calculating the level of local content in relation to goods and services among others. This method focuses on locally made goods and excludes the value of imported parts and it is also used to calculate local content of services by taking into account salaries and additional taxes of Brazilian citizens and foreigners who hold Brazilian permanent visas, It will be extremely helpful if the Board would tow this line. 


\section{ii Weak Capacity:}

Developing a strong local content largely depends on the manufacturing and construction strength of the country including its infrastructural base which are all lacking in Nigeria. The technology intensive nature of the Petroleum industry requires a strong manufacturing and industrial base for development for the service and supply firms to execute contracts related to engineering, fabrication, and so on. The absence of industrialization accounts for why Nigerian firms continue to depend on their foreign partners to provide the know-how even when they have been awarded the contract thereby making actual local content contribution minimal (Nwaokolo,2014).

iii Weak Infrastructural Base: A strong infrastructural base is the base upon which indigenous companies can develop. Nigerian roads, railway system, water transport is all in dire need of repairs and development. There is also the non-availability of electricitysupply which is an integral component for development of a manufacturing sector.

1v Ack of technological based institution resulting in Shortage of Skilled Man-power: There is constant brain drain resulting from bad leadership, corruption and economic depression which has caused a shortage of skilled and capable man-power. If the economy is improved and corruption minimized, it is believed that there will be an influx of Nigerian expatriates working in other countries returning to work in Nigeria. A strong and sound educational system is a good source of human capacity development. However, this is not the case for the Nigerian educational sector which is poorly funded; suffer frequent strikes with little or no research development. At the end of the day poorly trained graduates are churned out who cannot meet the technical demands of the oil and gas industry.

\subsection{Conclusion}

Local content in the petroleum industry in Nigeria was borne out of a sincere desire to increase local participation in the oil and gas industry and circumvent the dominance of the IOCs in the said industry. This paper finds that infrastructural development is the power base to drive local content. Further, the Nigerian Content Development and Monitoring Board should prosecute non-compliant companies to drive home the importance of local content in the oil and gas industry. Local Content Policies remain a key instrument of development in Nigeria arid any other resource-rich country. However, considering the current international legal constraints, resource rich countries may have to find alternative ways to adopt a cocktail of protectionist and liberal frameworks of employing local content and active participation in the industry to avoid the risk of being challenged. This paper finally concludes that Nigeria can take a cue from Brazil and Norway by looking at the peculiarities of the Nigerian oil and gas industry and adopting local content polies that will suit her peculiar situation. The paper makes the following recommendations:

\subsection{Recommendations}

1. It is therefore suggested that there should be Horizontal or non-specific measures, to entice companies to deploy efforts to source locally or to employ the local workforce.

2. There must be infrastructural development to drive the Local Content Act. The Nigerian government should inwardly develop the petroleum industry infrastructure without depending Foreign investors.

3. The Nigerian government should employ a holistic approach for measuring local content requirements and achievements attained with the aim of bridging the gap. NCDMB must have a holistic approach for measuring local content requirements and achievement like the approach used by the National Agency for Petroleum, Natural Gas and Bio Fuel, the regulator of the Oil and Gas sector in Brazil.

4. In addition, Institutional frameworks in partnership with the private sector, such as the development of suppliers' programmers, to accompany local suppliers in meeting requirements of extractive companies, accessing mining procurement, and sustaining supply on a long-term basis will also serve as a veritable means to a successful oil and gas structure in Nigeria. The NCDMB have to be stricter in enforcing the Act as some companies are still functioning without sanctions in the face of noncompliance.

5. There should be strong capacity foundation which will enhance the technical know-how capacity. When Nigerians are trained on the oil and gas explorations and technology, there will be a valid basis for excluding foreign participation for fear of foreign domination.

6. The waiver granted to some IOCs between 2010 and 2013 for the importation of relevant items due to lack of local capacity should be revisited until such a time when those sectors are properly developed. It is not a secret that some Nigerian companies usually outsource their contracts and the engineering feats ascribed to them in some cases were actually done by their foreign partners. This trend needs to be checked by a subsequent review of the law or anew regulation altogether. 


\section{References}

I want to express my gratitude to my LLM candidates Mr. JOHN CHIOMA NAOMI for his research in the area of local contents laws

1. Amadi T, \& Nse-Abasi Abraham, S, ( 2015) Enhancing the Effectiveness of Local Content Policy for Sustainable Development in Nigeria on line hps://wwwacademia.edu/18929574/enhancing the effectiveness of local content policy fir sustainable development in Nigeria accessed March 42020.

2. ANP the local content Regulation for concession agreement on line) https/www.braziltexas.org//attachment/file/401/ANP m-Marcelo.pdf accessed 8 March 2020.

3. Atsegbua L A, (2012) 'Nigeria Oil and Gas Content Development Act 2010: An Examination of its Regulatory Framework' 36 ( 4 ) OPEC Energy Review 479

4. Business World (2019) Applying Nigeria Content Development Levy in Oil Industry This day (Port Harcourt 25 September

5. Christopher, H (2009) A Push for Local Content 29:1 Oil and Gas Investors 10

6. CMS Law (2017) Brazil Proposes the relaxation of its local contents Requirements online /brazil-purposes relaxation of local contents-requirement, accessed 5March 2020

7. Dike, S C, (2015) 'Analyzing the Roles and Operations of Key Participant in the Nigerian Petroleum Industry and their' impact in Promoting Energy Security (2015) International Energy Law Review 180-181

8. Hunter, T (2014) "The Role of Regulatory Frameworks and state Regulations in Optimising the extraction of Petroleum Resources: A Study of Australian and Norway" The Extractive industry and Society 40-55

9. Kakonge, J ( 2011) Challenges of Managing Expectations of Newly Emerging Oil and Gas Producers of the South 'Journal of the World Energy Law\& Business 4, 128-129.

10. Bunter M (2002) The Promotion and Licensing of Petroleum Prospective Acreages. London: Kluwer Law International; P189-192

11. Nigeria Oil and Gas Industry Content Development Act, 2010, S 57

12. Nigerian Oil and Gas Industry Content Development Act, 2010.

13. Nwaokolo J E , (2014) 'Signed, Sealed and Delivered but Will it Deliver?: Nigeria's Local Content Bill and Cross Sectoral Growth . 4 ( 1) Journal of World Energy Law and Business 56

14. Pereowei Subai,(2019) Local Content Oil and Gas Law in Africa: Lessons from Nigeria and Beyond. London: Routledge 48-53

15. Petroleum Act 1969 Cap 10 Laws of Federation of Nigeria 2004

16. Petroleum Drilling and Production Regulation LN 1969 Regulation.

17. What is Local Contents (2019) on line http://www.investep.sa/LCI.html accessed September 24, 2019

18. OGCDA, Section 71(2), Local Content Act, 2010

19. OGCDA, Section 71(1), Local Content Act, 2010

20. OGCDA, Section 88, Local Content Act, 2010

21. OGCDA, Section 70, Local Content Act, 2010

22. OGCDA, Section 105

23. OGCDA, ,Section 3(1)

24. OGCDA, 12 and 13 .

25. OGCDA, 8 and 9.

26. OGICDA, S 3(2) .

27. OGCDA, Section 14

28. OGCDA S S 11(1) \& (4).

29. OGICDA SS 28-35 LCA, 2010

30. OGICDA Section $37-40$

31. OGCDA, s 64

32. OGCDA section 104 .

33. Oke, Y (2012)Multi-Jurisdictional Evaluation of the Nigeria Oil and Gas Industry and Content Development)" Act 2010 , 2 (2)University of Ibadan Journal 153-179

34. Omorogbe, Y (1997), Oil and Gas Industry ;Exploration and Production Contracts. Nigeria badan: Florence and Lombard, 4-6 